\title{
A Brief Summary of the Late Precambrian Rocks in the Caledonia Highlands of Southeastern New Brunswick*
}

\author{
A.A. RUITENBERG, P.S. GILES, D.V. VENUGOPAL and S.R. MCCUTCHEON
} Department of Natural Resources, Sussex, New Brunswick

The area referred to as the Caledonia Highlands is about 16 to $32 \mathrm{~km}$ wide and extends for about 160 $\mathrm{km}$ along the Bay of Fundy coast from Black's Harbour to Shepody Bay. Most of this belt is composed of Late Precambrian volcanic and sedimentary rocks, which are in part overlain by Cambrian, possible Silurian, and Carboniferous (and Upper Devonian?) sedimentary and minor volcanic rocks (see Fig. 1).

The Late Precambrian volcanic rocks of the Caledonia Highlands have been previously described in part by Hayes and Howell (1937), Alcock (1938), Flaherty (1933) and Kindle (1962). More recent work includes the radiometric age-dating studies of Cormier (1969) and analyses of structural and tectonic history by Brown and Helmstaedt (1970), Brown (1972), Ruitenberg (1969, 1970) and Ruitenberg et al (1973).

The Late Precambrian volcanic sequence in the northwestern part of the belt reflects a terrestrial environment, whereas rocks in the southeastern part have been mainly deposited along a basin margin. Base-metal sulphides are most abundant in the latter area. The volcanic sequence has been intruded by granitic to gabbroic bodies ranging in age from Ordovician to Carboniferous (or younger). These rocks have been studied in detail by Venugopal and McCutcheon (1974, in preparation).

The northwestern part of the Caledonia Highlands, has been poly-deformed during the Acadian (Middle Devonian) orogeny. The main phase of this deformation is characterized by upright close to isoclinal folds produced by northwest-southeast shortening. The southeastern and southern Caledonia Highlands have been deformed by intense cataclasis, which is thought to have resulted from upwarping or bending (under a lithostatic load) probably during Late Devonian and/or Early Carboniferous times. Subsequent deformation was dominated by block faulting and thrusting.

\section{Major Rock Units and Paleogeographic Setting}

The outcrop area of Late Precambrian rocks in the Caledonia Highlands can be divided into three broad belts, each of which is characterized by certain rock associations. These belts are termed the Southeastern, Central and Northwestern Volcanic Belts. The Southeastern and Central Volcanic Belts are separated by a broad linear area underlain by intrusive rocks, which has been designated the Central Intrusive Belt. The Central and Northwestern Volcanic Belts are separated by an area underlain by mainly plutonic rocks, which has been named the Northwestern Intrusive Belt.

The Southeastern Volcanic Belt, which extends from St. Martins to the Hillsborough area, is mainly composed of volcanogenic siltstone and tuff with lesser amounts of mafic and felsic flows. coarse-grained terrigenous detrital clastic sediments are intercalated with the volcanic rocks in the belt, and are most useful for stratigraphic correlation

* Manuscript received May 16, 1974. and delineation of rock units within the belt. Two thick ( $1000 \mathrm{~m})$ units, composed of red and green arkosic sandstone and conglomerate of fluvial and/or shallow marine origin, have been recognized.

The Central Volcanic Belt is characterized by abundant coarse lithic tuffs and flows with minor intercalated sediments. Coarse volcanic breccia and related small stocks, indicate the former presence of volcanic centres in this belt.

The Northwestern Volcanic Belt consists predominantly of felsic flows and tuffs. Stratigraphic relationships with the Central and Southeastern volcanic Belts are uncertain.

Our estimate of the thickness of the Coldbrook Group is about $10,000 \mathrm{~m}$. Thickness varies from $8200-12,500 \mathrm{~m}$ in the Southeastern Volcanic Belt, to $8000-9700 \mathrm{~m}$ in the Central volcanic Belt.

Demonstrable facies change between the Southeastern and Central Belts is considered proof of time equivalence of deposition in these two belts. The almost complete lack of evidence of subaqueous deposition (e.g. pillowed lavas, intercalated water-lain sediments) strongly suggests subaerial deposition for most of the volcanic rocks of the Central Volcanic Belt. The presence of ignimbritic rocks supports this interpretation. Centres of volcanic activity, as evidenced by subcircular stock like feeders surrounded by coarse breccia zones, are restricted to the Central Volcanic Belt, and appear throughout its length. It appears certain that many centres were simultaneously active during periods of intense volcanic activity, which might be expected to complicate detailed stratigraphic relationships.

The ubiquitous presence of volcanic flows in each belt throughout the stratigraphic succession indicates that conditions remained uniform with respect to proximity to source area, over long periods of geologic time. It seems probable that the Central Volcanic Belt occupied the area of volcanic activity throughout much of Late Precambrian time, although individual centres need not have remained active for great lengths of time.

Paleogeographic reconstruction based on the distribution of the major facies belts indicates that the volcanics of the Coldbrook Group were probably deposited along the margins of an intracratonic basin or a continental foreland. A belt of active vulcanism which roughly paralleled the basin margin, shed flows and pyroclastic material to the northwest and southeast. To the southeast, much of the finer pyroclastic debris was reworked by water to form volcanogenic sediments. Major streams flowing from the northwest carried material through the active volcanic belt and deposited it near the river mouths. Current activity distributed this material in broad belts parallel to the basin margin. 
LEGEND

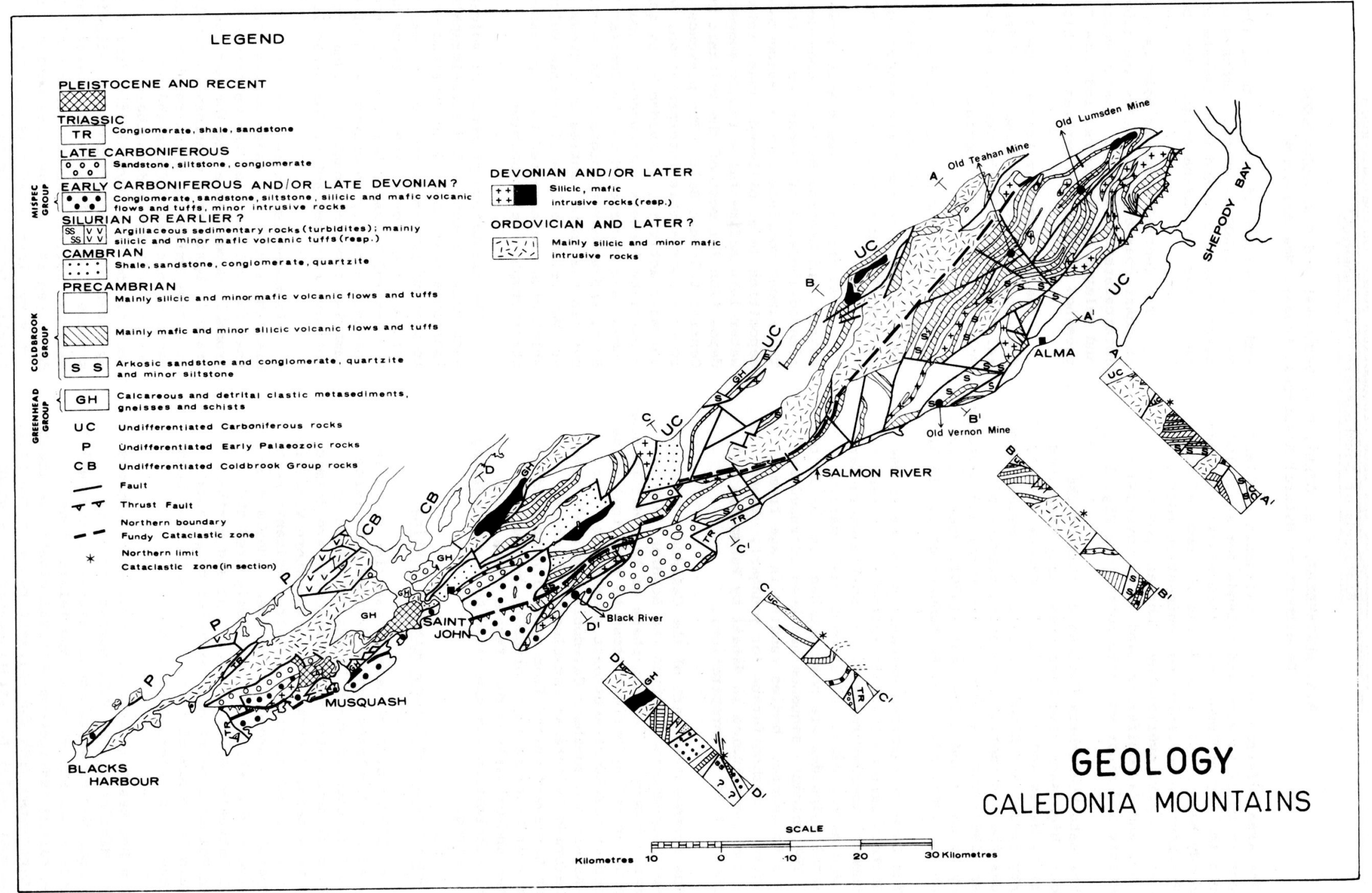


Although one may speculate that our basin margin represents a continental margin, caution must be stressed, since bilateral intracratonic basins have been documented in the more southwesterly Appalachians during Late Precambrian time (Hadley, 1970). The unilateral nature of our proposed model may simply reflect current geographic limitations of the study area.

\section{Intrusive Rocks}

Three distinct Palaeozoic phases of plutonic rocks have been delineated in the Caledonia Highlands. An earlier phase of plutonic activity is indicated by the occurrence of granite boulders and cobbles in the coldbrook Group (and equivalent) sedimentary rocks of Late Precambrian age. Large plutons, extending for several tens of $\mathrm{km}$, were emplaced in a major northeast-southwest trending distensional zone, probably during Ordovician time. These rocks intrude the sedimentary and volcanic rocks of the coldbrook Group (and equivalent) and range in composition from quartz-diorite to granodiorite. The second intrusive phase culminated, at least in part, with the cataclastic deformation during the Late Devonian and/or Early Carboniferous. These intrusions are mainly potash-rich granite and occur as numerous dikes and sills. The last plutonic activity took place subsequent to this cataclastic deformation. The intrusive rocks of this suite range in composition from quartz-diorite to peridoite although most of the rocks fall in the range of diorite and gabbro.

\section{Structural Geology}

Several structural zones have been delineated in the Caledonia Highlands. Each of these zones is characterized by a distinct tectonic style. The structural zones coincide in part with lithologic belts described above.

The Late Precambrian volcanic sequence (Coldbrook Group) in the northwestern part of the Caledonia Highlands is separated by major northeasttrending faults from deformed Palaeozoic rocks to the northwest, and older Precambrian metasedimentary rocks (Green Head Group) and Ordovician(?)

intrusions to the southeast. The Coldbrook Group in this zone has been subjected to similar deformation as the Palaeozoic rocks to the northwest, which occurred during the Midale Devonian (Acadian) orogeny (Ruitenberg, 1967, 1968, 1969, 1970, 1972, 1973; Brown and Helmstaedt, 1970; Brown, 1972; Garnett, 1972). In both these zones, the structure is characterized by a steeply dipping penetrative foliation $\left(s_{1}\right)$, roughly parallel to axial surfaces of steeply to gently plunging; close to isoclinal folds (Group 1). Lineations $\left(L_{1}\right)$ in $s_{1}$ surfaces are mainly defined by deformed clasts and by actinolite in some metamorphosed mafic rocks of the Coldbrook Group (Brown and Helmstaedt, 1970). $\mathrm{J}_{1}$ lineations are parallel to axes of Group $I$ folds. Major isoclinal folds with limbs of more than $1 \mathrm{~km}$ across have been mapped by P.S. Giles and S.R. McCutcheon in the Kingston Peninsula in the northeastern part of this zone, where good marker horizons are present. Bedding $\left(S_{0}\right)$ and cleavage $\left(s_{1}\right)$ in these rocks have been deformed by a crenulation cleavage $\left(S_{2}\right)$ in this area. $S_{2}$ surfaces are roughly defined by a coarse fracture cleavage, which parallel the axial surfaces of gently plunging folds (Group 2). Small chevron folds (Group 3) have locally deformed $s_{0}, s_{1}$, and $s_{2}$.

A few radiometric dates are available for deformed rocks of the coldbrook Group and intrusive rocks, which cut across this volcanic sequence. Wanless et al (1967) gave a $\mathrm{K}-\mathrm{Ar}$ age of $367 \pm 21 \mathrm{my}$ for actinolite from metamorphosed mafic rocks of the Coldbrook group. Plutonic rocks in this area which yielded $K-A r$ ages of $473 \pm 26 \mathrm{my}$ and $495 \pm$ 27 my (cf Ruitenberg, 1970) show a well developed SI cleavage roughly parallel to those in the coldbrook volcanic rocks. Younger silicic dykes in this area, which yielded a K-Ar age of $334 \pm 18$ my show no cleavage. This data is compatible with a Middle Devonian (Acadian) age for this deformation.

A second zone of intense penetrative deformation referred to as the "Fundy Cataclastic zone" (Ruitenberg et al, 1973), comprises Late Precambrian rocks (equivalents of Coldbrook Group) along the Bay of Fundy coast and the southeastern margins of the large intrusions in the northeastern part of the Caledonia Highlands. The southwestern part of the Fundy Cataclastic Zone cuts across the Mispeck Group of Late Devonian or Early Carboniferous age.

The "Fundy Cataclastic zone" forms a major northeast-trending upwarped belt, defined by a well developed foliation $\left(S_{1}\right)$. This major structure differs markedly from that of the intensely polydeformed rocks, in the northwestern part of the Caledonia Highlands (described above). Attitudes of the $s_{l}$ surfaces vary from nearly horizontal to moderate (rather than steep as in the northwestern part of the Caledonia Highlands), where they have not been effected by intense late stage folding. Local steep dips of $\mathrm{S}_{1}$ and major changes in trends were produced by later folding and faulting. In the southeastern part of the "Fundy Cataclastic zone", east and west of Saint. John, intensely deformed rocks have, at least in part, been thrust over weakly deformed or undeformed rocks to the north. In the northeastern part of the zone, the boundary approximates the contact between the major Ordovician(?) granitic pluton and the volcanic sequence (Coldbrook Group equivalents) to the southeast.

The penetrative cleavage $\left(S_{1}\right)$ is most prominent in the finer grained tuffaceous and sedimentary rocks in the "Fundy Cataclastic Zone". In localities where both bedding $\left(S_{0}\right)$ and cleavage $\left(S_{1}\right)$ can be distinguished, they are approximately parallel, although cross-cutting relationships have also been observed. Deformed pebbles and clasts have locally been stretched in a preferred direction parallel to $S_{1}$, producing well defined lineations $\left(\mathrm{L}_{1}\right)$, but many have been intensely crushed and flattened without showing a distinct direction of elongation.

Three groups of mesoscopic folds have been recognized in this deformed zone. In a few localities, $S_{1}$ is roughly parallel to axial surfaces of gently plunging Group 1 folds with limbs that vary in size from mesoscopic to several metres. 
$L_{1}$ mineral lineations are oblique to Group $I$ folds axes $\left(B_{1}\right)$. Our detailed mapping of several well exposed sections in this zone has, however, not produced evidence for regional Group 1 folds. $S_{0}$, $\mathrm{S}_{1}$, and $\mathrm{L}_{1}$ were folded during a second deformation throughout most of this deformed zone. Group 2 folds are open to close, and mostly gently plunging. They vary in size from small crenulations of $s_{1}$ to regional folds. An irregular fracture cleavage has been developed approximately parallel to the axial surfaces $\left(\mathrm{S}_{2}\right)$ of these folds. The attitudes of the irregular $\mathrm{S}_{2}$ surfaces vary greatly over short distances, but dips are mostly small to moderate. Many Group 2 folds are distinctly asymmetric and over-turned to the northwest or southeast. Evidence has been found for a third deformation, mainly in the northeastern part of the Fundy Cataclastic Zone. Intense slip, roughly parallel to $S_{1}$, produced open to close, chevron-type folds and flexures (Group 3), which plunge at varying angles towards the northeast, northwest, southwest or southeast. Group 3 folds have deformed $\mathrm{L}_{2}$ lineations and Group 2 folds as seen in exposures subjected to both types of deformation. Where both Group 2 and Group 3 are well developed, typical "egg-carton" shaped interference structures are common.

Numerous northwesterly and northeasterly striking, mostly steeply dipping faults up to $22 \mathrm{~km}$ in length truncate major rock units. These structures cut across Group 3 folds and earlier structures. Slickensides commonly indicate reverse and normal dip slip as the latest movement along the fault surfaces. Low-angle thrusts have been mapped east and west of Saint John. Rast and Grant (1973) made a detailed study of these thrusts in the Maces Bay area, west of Saint John.

Al1 structures in the "Fundy Cataclastic Zone" except Group 3 folds, appear to reflect distinct stages in the development of the major upwarped structure defined by $S_{1}$ and $S_{0}$. Extension parallel to $S_{1}$ (and $S_{0}$ ) resulted most likely from upwarping or bending (under a lithostatic load), which was produced by vertical movements of basement blocks underlying deformed layers. Mesoscopic Group 1 folds are rare and they have probably developed only along the margins of uplifted blocks, where overlapping of shearing and flattening was most likely to occur. Continued upwarping provided the slopes along which Group 2 folds could form by gravity sliding. Finally all the structures formed earlier were truncated mainly by high-angle faults and, locally, low angle thrusts.

The time of this cataclastic deformation is not entirely certain. The coldbrook (and equivalents) and Mispeck Groups in the Fundy Cataclastic Zone appear to have been deformed simultaneously. However, the age of the Mispeck Group is problematic. Plant fragments have been found in several localities, but their age has not been positively determined. Deformed rocks of this group at Mispeck Point contain boulders of grey granite lithologically similar to the Middle Devonian (387 $\pm 11 \mathrm{my}$; Tupper and Hart, 1961) St. George granite. It appears therefore that this deformation post-dates emplacement of this batholith.

In the Black River area, east of Saint John, felsic sills intruding Mispeck sedimentary rocks have been dated at $322 \pm 20$ and $338 \pm 20$ my (cf Ruitenberg, 1970). The margins of these sills have been deformed during the development of the Fundy Cataclastic Zone. This suggests that this deformation continued at least into Mississippian time.

The deformed coldbrook and equivalent rocks in the northeastern Caledonia Highlands are overlain by undeformed conglomerates of the Memramcook Formation, which contain deformed cobbles of coldbrook lithologies. The Memramcook underlies or is in part equivalent to the Albert Formation (also undeformed), which ranges from Late Devonian to the Lower Mississippian in age (oral communication, H.R. Greiner, 1974). This suggests that the cataclastic deformation had effectively ceased, in this area, prior to the Lower Mississippian.

The evidence at Mispeck Point indicates that the cataclastic deformation post-dates the Middle Devonian (Acadian) orogeny. The $\mathrm{K}-\mathrm{Ar}$ dates from the Black River area would extend the time of deformation at least into the Mississippian. However, sedimentological and paleontological evidence from the northeastern Caledonia Highlands indicate that this deformation ceased, in this area, prior to Mississippian time. It is possible that: a) the deformation continued longer in the Black River area, or $\mathrm{b})$ the $\mathrm{K}-\mathrm{Ar}$ dates reflect a slight argon loss during this deformation. The authors favour the second interpretation. It is notable that deformation associated with reverse and normal dip-slip faults and thrusts post-dates the major penetrative phase of this deformation, in the investigated area.

\section{References}

AICOCK, F.J., 1938, Geology of Saint John region. Canada Geol. Surv. Mem. 216, pp. 65.

BROWN, R.L., 1972, Appalachian structural style in southern New Brunswick. Can. Jour. Earth sci., vol. 9, pp. 43-53.

, and HELMSTAEDT, H., 1970, Deformation history in part of the Lubec-Belleisle zone of southern New Brunswick. Can. Jour. Earth Sci., vol. 7, pp. 748-767.

CORMIER, R.F., 1969, Radiometric dating of the Coldbrook Group of southern New Brunswick, Canada. Can. Jour. Earth Sci., vol. 6, pp. 393-398.

HADLEY, J.B., 1970, The Ocoee Series and its possible correlatives: in studies of Appalachian geology-central and southern. Edition by G.W. Fisher, F.J. Pettijohn, J.C. Reed, Jr., and K.N. Weaver, Interscience Publishers, New York, pp. 247-259.

HAYES, A.O., and HOWELL, B.G., 1937, Geology of Saint John, New Brunswick. Geol. Soc. America Spec. Paper 5, pp. 146.

RAST, N., and GRANT, R., 1973, Transatlantic correlation of the Variscan-Appalachian 
orogeny. Am. Jour. Sci., vol. 373, pp. 572579 .

RUITENBERG, A.A., 1967, Stratigraphy, structure and metallization, Piskahegan-Rolling Dam area. Leidse Geol. Meded., vol. 40, pp. 79-120.

1968, Geology and mineral deposits, Passamaquoddy Bay area. New Brunswick Dept. Nat. Resources Mineral Devel. Br. Rept. Inv. 7, pp. 47 .

1969, Mineral deposits in granitic intrusions and related metamorphic aureoles in part of Welsford, Loch Alva, Musquash and Pennfield areas. New Brunswick Dept. Nat. Resources Mineral Devel. Br. Rept. Inv. 9, pp. 24 .
1970, Mineralized structures in the Johnson Croft, Annidale, Jordan Mountain and Black River areas. New Brunswick Dept. Nat. Resources Mineral Devel. Br. Rept. Inv. 13, pp. 26 .

, 1972, Metallization episodes related to tectonic evolution, Rolling Dam amd Mascarene-Nerepis belts, New Brunswick. Econ. Geology, vol. 67, pp. 434-444.

VENUGOPAL, D.V., and GILES, P.S., 1973, "Fundy Cataclastic Zone", New Brunswick: Evidence for Post-Acadian penetrative deformation. Geol. Soc. America Bull., vol. 84, pp. 3029-3044.

WANLESS, R.K., STEVENS, R.D., LACHANCE, G.R., and EDMONDS, C.M., 1967, Age determinations and geological studies- K-Ar isotopic ages. Canada Geol. Surv. Paper 67-2, pt. A., pp. 123. 